\title{
ANALISIS KEMUNCULAN AWAN HUJAN BERDASARKAN JENISNYA UNTUK MENDUKUNG KEGIATAN MODIFIKASI CUACA
}

\author{
Findy Renggono ${ }^{1)}$ \\ ${ }^{1}$ UPT. Hujan Buatan BPPT, Jalan. M.H.Thamrin No.08 Jakarta Pusat
}

\begin{abstract}
Intisari
Untuk memenuhi kebutuhan cadangan air di tiga danau yang ada di DAS Larona, telah beberapa kali dilakukan penyemaian awan dengan menggunakan Teknologi Hujan Buatan. Teknologi yang selama ini dilakukan adalah penyemaian awan dari udara dengan menggunakan pesawat terbang sebagai sarana penghantar bahan semainya. Namun akhir-akhir ini di Balai Teknologi Modifikasi Cuaca, $B P P T$ telah mulai dikembangkan teknologi penyemaian awan dari darat yang menggunakan menara. Penempatan menara ini perlu mempertimbangkan unsur meteorologi agar bahan semai secara efektif dapat masuk ke dalam awan yang potensial menghasilkan hujan. Dari data satelit dan penakar hujan didapatkan gambaran secara umum sebaran awan hujan. Dengan melakukan analisis reflektifitas radar diperoleh sebaran awan hujan berdasarkan jenis awan hujannya. Dengan metoda ini diketahui bahwa awan-awan hujan yang muncul di Matano, Timampu dan Tokalimbo kebanyakan awan hujan jenis shallow convective. Awan hujan shallow convective dan convective pada bulan Januari-Maret lebih banyak tumbuh di bagian Utara dan Timur DAS. Di bagian tengah DAS, kemunculan awan hujan lebih sedikit.
\end{abstract}

Kata Kunci: radar, awan hujan, sorowako, modifikasi cuaca

\begin{abstract}
Cloud seeding project has been carried out in Larona watershed to enhanced the rainfall in this area. Until now the cloud seeding technology has been done by delivering the seeding material directly to the cloud by aircraft. But recently, the National Laboratory of Weather Modification Technology of Indonesia is developing a new method of ground based seeding by building some towers for delivering the seeding agent to the cloud. Location of the tower should consider elements of Meteorology in order for the seeding materials can effectively enter into cloud which potentially produce rain. By doing an analysis of the radar reflectivity obtained the distribution of clouds based on the type of precipitation cloud. With this method it is known that rain clouds that appeared in Matano, Timampu and Tokalimbo are mostly shallow convective clouds. In January-March, shallow convective clouds and convective grew more in the North and East of the Larona watershed. In the central part of the watershed, there is less precipitating clouds appear.
\end{abstract}

Keywords: radar, rain cloud, sorowako, weather modification

\section{PENDAHULUAN}

DAS Larona mempunyai pola iklim yang unik karena lokasinya yang diapit oleh laut di sebelah barat dan timurnya, selain itu juga di dalam DAS terdapat badan air yang cukup dalam dan luas, yaitu danau Matano, Mahalona dan Towuti (Gambar 1). Ke tiga danau membentuk danau kaskade yang mengalir ke teluk Bone melalui sungai Larona dari danau Towuti. Pola hujan di wilayah ini secara umum mempunyai satu puncak musim hujan yaitu di bulan April dan terus menurun sampai bulan Desember, namun kadang-kadang terjadi curah hujan yang agak tinggi di bulan Oktober.

Pengaturan air di ketiga danau ini menjadi penting karena air keluarannya digunakan untuk menggerakkan turbin pembangkit tenaga listrik, yang kemudian sebagai pemasok utama listrik bagi tambang nikel dan masyarakat sekitar. Air yang mengalir dari danau Towuti masuk ke tiga PLTA, yaitu Larona, Balambano, dan Karebbe dengan produksi daya listrik total sekitar 365 megawatt. Jika air danau berkurang, turbin tidak dapat berputar, sehingga tidak dapat menghasilkan listrik. Untuk itulah perlu dilakukan kajian terhadap iklim dan 
cuaca di wilayah ini, sekaligus perlu dilakukan kajian untuk antisipasi jika terjadi kekurangan air hujan, salah satu alternatifnya adalah dengan teknologi modifikasi cuaca.

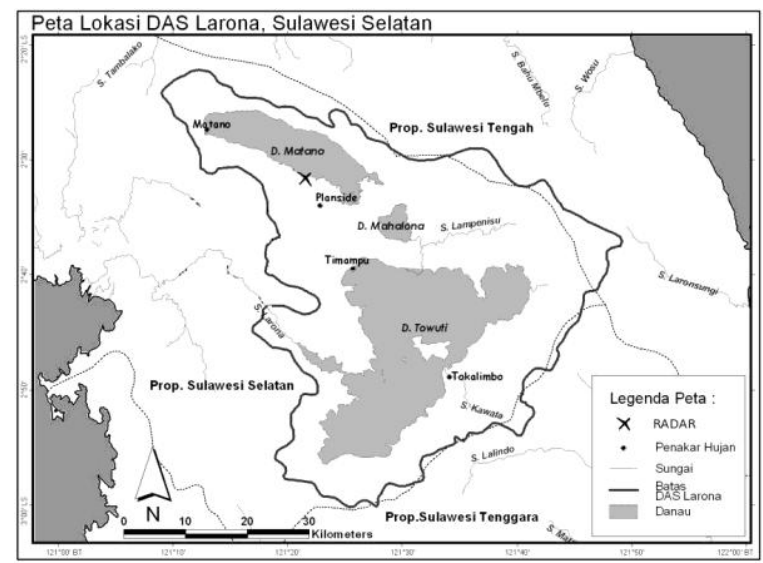

Gambar 1. Peta lokasi kegiatan pengamatan awan hujan di DAS Larona

Teknologi Modifikasi Cuaca untuk menambah curah hujan merupakan teknologi yang telah banyak dilakukan di seluruh dunia, salah satunya yaitu dengan cara melakukan penyemaian awan. Bahan semai yang digunakan adalah bahan higroskopis yang dimasukkan ke dalam awan kumulus dengan tujuan memicu terjadinya tumbukan dan penggabungan sehingga dapat mempercepat terjadinya hujan sekaligus menambah curah hujan. Penyemaian dapat dilakukan dengan dua metoda, yaitu dengan menggunakan pesawat, atau dengan menara yang dipasang di tempattempat yang banyak ditumbuhi awan. Penggunaan radar sebagai alat bantu untuk memantau jenis dan keberadaan awan dalam kegiatan penyemaian awan menjadi hal yang mutlak.

Penelitian sebelumnya menunjukkan bahwa pola sebaran hujan di DAS Larona dipengaruhi oleh pergerakan angin skala sinop (Renggono, 2011a). Namun dalam penelitian tersebut, penulis tidak membedakan jenis hujannya, hanya melihat jumlah akumulasi total dari reflektifitas radar. Selain itu data yang digunakan juga hanya data bulan Maret 2010.

Penelitian tentang kemunculan awan hujan di Serpong yang diamati dengan L-band radar telah dilakukan oleh Renggono dkk (2001) dengan menggunakan metoda pembagian jenis awan yg diberikan oleh Williams dkk (1995). Wang (2001) mengajukan algoritma untuk mendeteksi awan dengan menggabungkan berbagai macam pengukuran lain selain radar, seperti misalnya lidar dan radiometer, sedangkan Yang (2013) melakukan klasifikasi awan hujan dengan metode fuzzy logic.

Tulisan ini bertujuan untuk melihat pola sebaran awan hujan konvektif di wilayah DAS Larona untuk menentukan lokasi-lokasi yang banyak ditumbuhi awan, khususnya awan konvektif, dalam rangka menyusun strategi penyemaian awan untuk menambah curah hujan. Selain itu, hasil dari penelitian ini juga diharapkan dapat berguna dalam menentukan lokasi penempatan menara penyemai awan, yaitu media penyalur bahan semai ke awan dari darat yang akhir-akhir ini dikembangkan oleh BPPT. Penentuan lokasi menara ini sangat penting, karena kesalahan penempatan menara dapat berakibat tidak terdisbusinya bahan semai ke awan. Kegunaan lain adalah untuk menetukan lokasi pemasangan alat ukur meteorologi permukaan, sebagai bahan monitoring dan evaluasi kegiatan.

\section{BAHAN DAN METODE}

Wilayah pengamatan hujan pada tulisan ini adalah DAS Matano yang terletak di Sulawesi Selatan (gambar 1). Data yang digunakan untuk menentukan kemunculan dan jenis awan adalah data hasil pengamatan dengan radar cuaca yang terletak di dalam wilayah bandara Soroako (121.35E, 2.53S, tanda silang (x)), sedangkan untuk mengetahui curah hujan historis digunakan data dari data presipitasi TRMM (Tropical Rainfall Measuring Mission) dan penakar manual di tiga lokasi, yaitu Matano, Timampu dan Tokalimbo.

Data TRMM yang digunakan adalah data prsipitasi yang diolah oleh JAXA (ftp://hokusai.eorc.jaxa.jp). Data TRMM dari Jaxa ini mempunyai kerapatan spasial yang cukup baik, yaitu sekitar 0.1 derajat dengan kerapatan waktu satu jam. Penelitian sebelumnya mengenai pengamatan curah hujan pada tiga daerah aliran sungai (DAS) menunjukkan bahwa data TRMM Jaxa mempunyai korelasi yang lebih baik dibandingkan dengan data TRMM NASA (Syaifullah, 2014). Pada tulisan ini digunakan data presipitasi untuk wilayah DAS Larona yang diolah oleh Syaifulah (2014).

Tabel 1. Ketersediaan data C-band radar

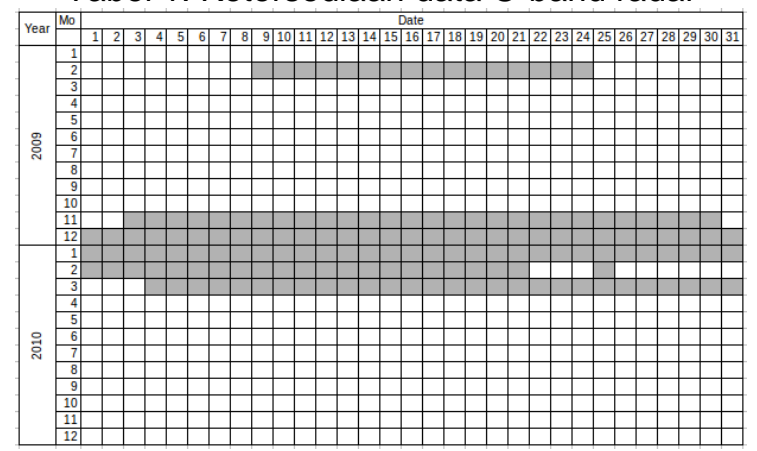

\subsection{Radar Cuaca}

Radar cuaca yang dipasang di Sorowako merupakan Doppler C-band radar, yang sesuguhnya merupakan radar buatan (Enterprise Electronics Corporation) EEC tipe WSR-74C yang telah diupgrade oleh Advanced Radar Corporation (ARC), 
terutama pada bagian pengolahan sinyal dan pengolahan parameter radar. Radar yang mulai beroperasi pada tahun 2008 ini bekerja pada frekuensi $5.33 \mathrm{GHz}$, dengan lebar beam 1.6, dan mampu mendeteksi butir hujan sampai radius $100 \mathrm{~km}$. Karena utamanya digunakan untuk mendukung kegiatan modifikasi cuaca, maka radar inipun diperlengkapi dengan piranti lunak TITAN buatan NCAR yang mampu melakukan analisis untuk mendukung kegiatan penyemaian awan.

Pada tulisan ini, data radar yang digunakan adalah data bulan Desember 2009 sampai Maret 2010, pada saat diadakannya kegiatan Modifikasi Cuaca di DAS Larona. Pengamatan hanya dilakukan dari pukul 10.00 sampai 17.00. Tabel ketersediaan data dapat dilihat pada tabel 1 di atas. Warna gelap menunjukkan adanya data, sedangkan warna cerah menunjukkan sebaliknya. Data dianalisis setiap grid $(600 \times 600)$ untuk 10 level ketinggian setiap 6 menit. Parameter yang diperoleh dari pengamatan ini adalah reflektifitas, lokasi, dan ukurannya (besar dan tebal awan). Dengan mengamati parameter-parameter tersebut dilakukan analisis kemunculan awan konvektif dan dihitung jumlah kemunculannya dalam setiap bulan dari Nopember 2009 sampai Maret 2010.

\subsection{Awan Hujan Konvektif}

Hujan yang terjadi dari awan hujan konvektif dapat dicirikan sebagai awan hujan yang menjulang cukup tinggi dan mempunyai butir air yang cukup besar dengan curah hujan lebih dari 10mm/jam. Dalam penelitiannya, Leary and Houze (1979) menyebutkan bahwa reflektifitas radar yang mempunyai nilai tinggi dari awan hujan konvektif akan berbentuk menjulang secara vertikal, berbeda dengan awan hujan jenis stratiform yang terlihat memanjang secara horizontal. Dalam penelitian ini data reflektifitas dari C-band radar akan dianalisis berdasarkan definisi di atas. Data radar yang mempunyai reflektifitas dengan nilai ambang tertentu dan ketebalan minimal tertentu dikategorikan sebagai awan konvektif atau stratiform.
Pembagian jenis awan hujan dilakukan dengan beberapa kriteria menjadi tiga jenis, yaitu: (1) awan hujan konvektif (convective, CNV), yaitu awan hujan konvektif yang tingginya lebih dari freezing level, (2) awan hujan konvektif rendah (shalow convective, SHL), yaitu awan hujan konvektif yang tingginya kurang dari freezing level, dan (3) awan hujan stratiform (STR). Pada umumnya di Indonesia ketinggian freezing level sekitar $4-5 \mathrm{~km}$. Di sini diambil nilai batasnya adalah $5 \mathrm{~km}$. Syarat batas untuk reflektifitasnya adalah $20 \mathrm{dBZ}$, sama dengan yang digunakan oleh Renggono (2015) pada analisis hujan untuk wilayah DKI Jakarta.

Contoh potongan tegak lurus reflektifitas radar untuk tanggal 31 Maret 2010 pukul 0704 pada 2.92S ditunjukan pada gambar 2(atas). Pada gambar ini terlihat reflektifitas awan yang tegak menjulang di 121.62 dan 121.72, yang merupakan awan CNV dan reflektifitas mendatar di 121.77121.85 yang merupakan awan STR. Dengan menggunakan parameter dan nilai batas seperti yang disebutkan di atas, kemunculan masingmasing jenis awan seperti yang terlihat pada gambar ini dapat diidentifikasi secara otomatis.

\subsection{Metode Penentuan Jenis Awan Hujan}

Untuk menentukan jenis awan, dibuat algoritma yang dapat secara otomatis menghitung semua parameter-parameter sesuai dengan teori pada (2.2). Seluruh data reflektifitas radar diperiksa apakah mempunyai ketebalan dan tinggi tertentu. Untuk itu, nilai ambang $20 \mathrm{dBZ}$ merupakan batas dimana reflektifitas radar dianggap mengandung cukup uap air yang menghasilkan hujan. Dengan mengamati nilai ambang tersebut dapat diketahui batas atas dan batas bawah dari awan, sekaligus total tebal awan hujannya. Gambar 2 merupakan contoh hasil perhitungan tinggi top dan base dari awan. Pada gambar 2 (atas) adalah reflektifitas radar yang telah dihitung nilai ketinggian top nya (garis solid tebal) dan ketinggian base nya (garis solid tipis). Gambar 2 (bawah) merupakan total tebal awan hujan tersebut. Pada gambar ini nilai tebal awan kurang dari $1 \mathrm{~km}$ tidak dianggap awan hujan yang bisa menghasilkan hujan. 


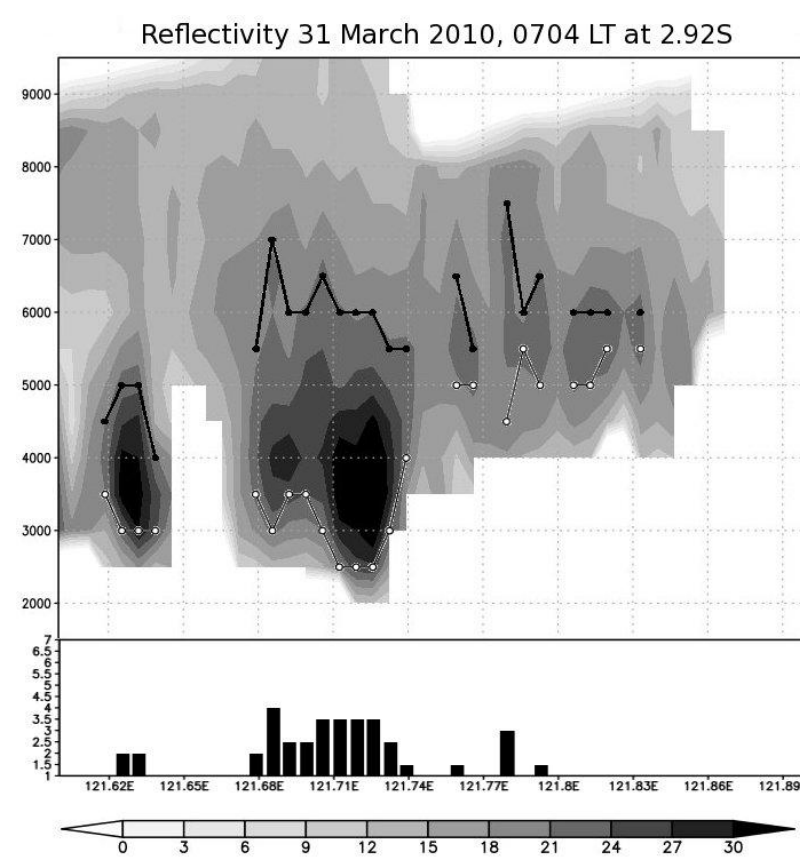

Gambar 2. Contoh irisan vertikal reflektifitas radar dengan garis solid tebal merupakan batas top awan dan solid tipis adalah tinggi base awan (atas) dan hasil perhitungan ketebalan awan (bawah).

Seluruh awan hujan yang mempunyai ketebalan lebih dari $1 \mathrm{~km}$ selanjutnya masuk ke proses seleksi sesuai dengan algoritma yang ditunjukkan pada gambar 3. Jika awan tersebut mempunyai dasar awan di atas $3.5 \mathrm{~km}$ dan to lebih dari $5 \mathrm{~km}$ maka awan tersebut masuk dalam katagori awan hujan CNV. Jika awan tersebut tinggi dasar awannya di atas $3.5 \mathrm{~km}$, berarti awan tersebut merupakan awan STR. Sedangkan awan tebal namun tingginya tidak mencapai $5 \mathrm{~km}$ masuk sebagai awan SHL.

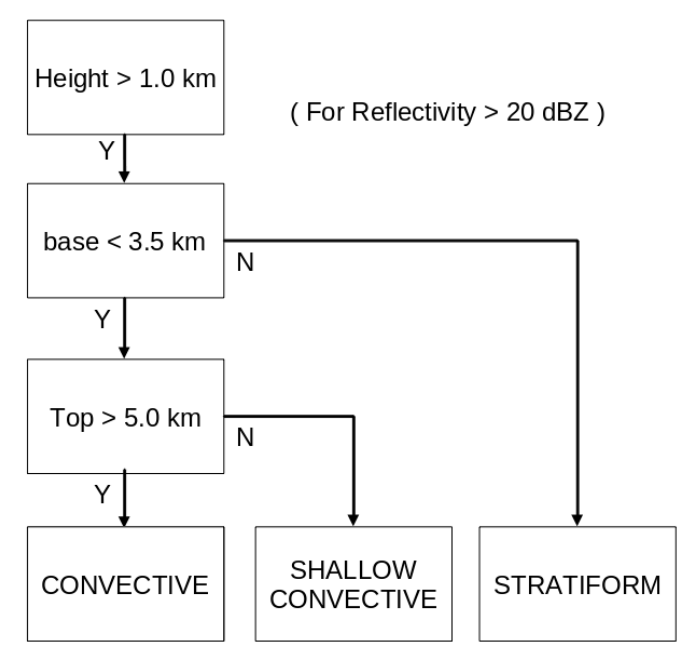

Gambar 3. Diagram alir metoda penentuan jenis awan dari reflektifitas radar.

\section{HASIL DAN PEMBAHASAN 3.1 Variasi Hujan Harian di DAS Larona}

Pada penelitian sebelumnya disebutkan bahwa variasi hujan di DAS Larona mengikuti pola monsunal (Aldrian, 2006). Hasil pengamatan variasi hujan tahunan dengan penakar hujan manual antara tahun 1996 sampai 2005 di Matano, Timampu dan Tokalimbo dapat dilihat pada gambar 4a. Terlihat disini bahwa Puncak musim hujan di ketiga wilayah tersebut adalah pada bulan April, dan bulan paling sedikit hujan adalah bulan September. Pada bulan Januari sampai Maret, kecuali di Timampu, rata-rata hujan bulanannya sekitar $300 \mathrm{~mm}$, namun seluruhnya masih diatas $200 \mathrm{~mm} /$ bulan.

Untuk mengetahui variasi hariannya, digunakan 21 grid data TRMM JAXA tahun 2014 yang dirata-rata untuk satu wilayah DAS (diambil dari http://wxmod.bppt.go.id/index.php/monitoringtrmm-tmc-das). Terlihat pada gambar $4 \mathrm{~b}$ bahwa hujan lebih banyak muncul pada siang hari. Di bulan Januari puncak hujan adalah pukul 15, sedangkan Februari dan Maret lebih awal, yaitu setelah lewat tengah hari sekitar pukul 13.
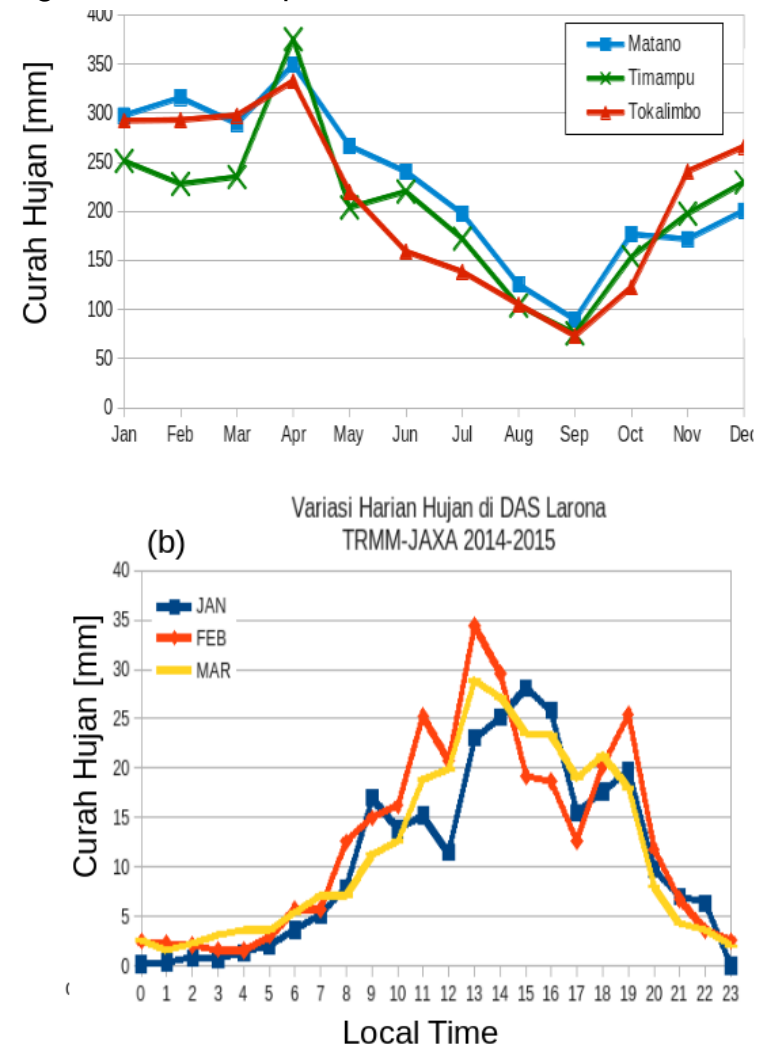

Gambar 4. Variasi hujan tahunan dari penakar hujan manual tahun 1997-2005 (a), dan variasi hujan harian dari data TRMM-JAXA tahun 20142015

\subsection{Kemunculan Awan Hujan}

Untuk menghitung kemunculan awan, dilakukan penghitungan jumlah awan berdasarkan 
jenisnya selama pengamatan radar bulan Januari sampai Maret 2010. Seperti yang telah diterangkan di atas, pengamatan radar hanya berlangsung antara pukul 8 sampai 17 setiap hari, sehingga hujan yang dihitung dalam penelitian ini hanya hujan yang terjadi siang hari. Pada tulisan ini akan dilihat kemunculan awan hujan di tiga lokasi, yaitu Matano (121.2162BT, 2.4565LS), yang berada di sisi Barat DAS, Timampu (121.4282BT, 2.6573LS), yang berada di tengah, dan Tokalimbo (121.5679BT, 2.8148LS) yang berada di sisi Timur (lihat gambar 1). Hasil perhitungan jumlah awan hujan yang muncul di ke tiga lokasi tersebut dapat dilihat pada gambar 5.

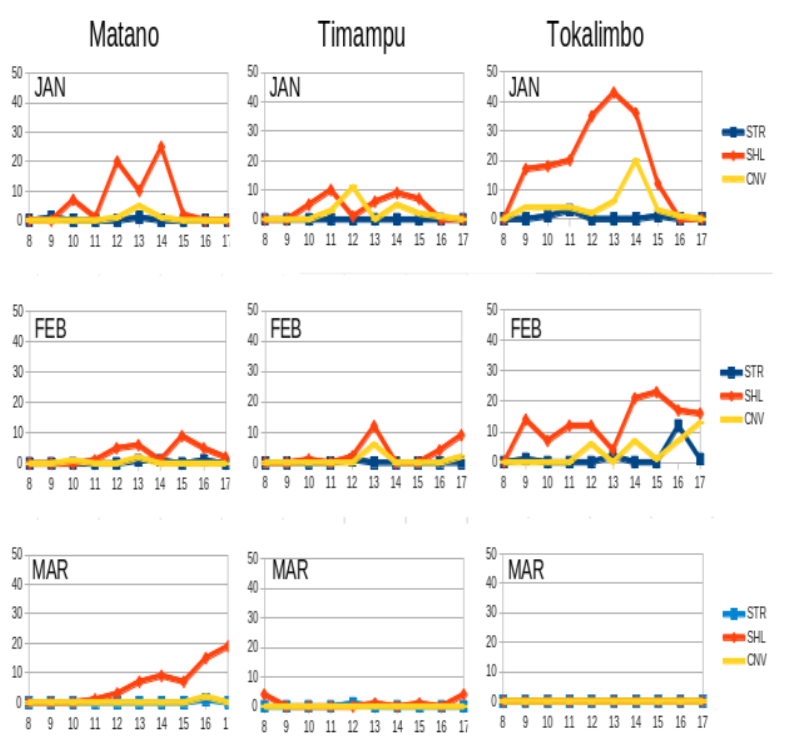

Gambar 5. Kemunculan awan STR, SHL dan CNV pada bulan Januari-Maret 2010 di tiga lokasi, Matano, Timampu dan Toklimbo

Pada gambar ini terlihat pada bulan Januari semua grafik menunjukkan bahwa hujan SHL lebih banyak terjadi, dan kejadian hujannya kebanyakan terjadi setelah pukul 11 dan puncaknya sekitar pukul 13-14 siang hari. Puncak untuk awan CNV terlihat hampir sama atau lebih lambat dari awan SHL, sedangkan kemunculan hujan STR terlihat sangat sedikit. Pada bulan Februari-Maret tampak bahwa kemunculan awan SHL (dan CNV) lebih sedikit pada siang hari namun pada pukul 17 masih terlihat banyak awan SHL (Matano dan Tokalimbo bulan Februari, serta Timampu bulan Maret).

\subsection{Sebaran Hujan}

Gambar 6 merupakan contoh sebaran awan hujan yang dianalisis menggunakan metoda identifikasi jenis awan seperti yang dijelaskan pada (2.3). Gambar ini merupakan data hujan tanggal 31 Maret 2010 pukul 0704 UTC. Pada gambar ini diketahui bahwa di dalam DAS banyak bermunculan awan-awan hujan SHL, namun sebagian besar awan hujan jenis CNV dan SHL terlihat di dekat outlet dari danau Towuti (sisi barat danau Towuti). Sedangkan di luar DAS, awan-awan hujan jenis CNV dan STR lainnya juga banyak bermuculan di batas DAS bagian Selatan, dan di bagian Barat Laut DAS tampak awan-awan jenis SHL.

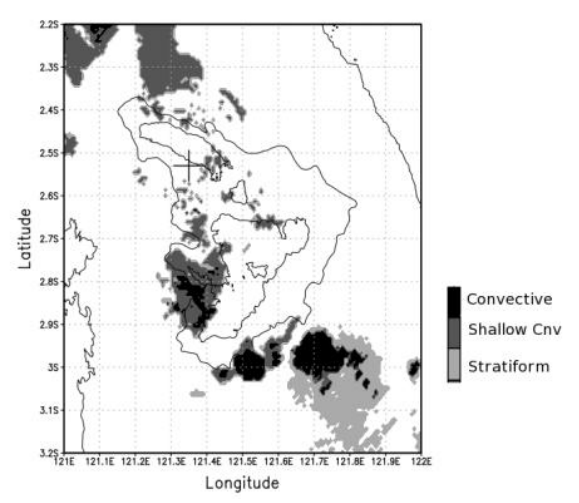

Gambar 6. Contoh sebaran hujan di DAS Larona.

Untuk mengetahui frekuensi kemunculan jenis awan tertentu, dilakukan akumulasi jumlah kemunculan awan berdasarkan jenisnya seperti yang terlihat pada gambar 7. Gambar ini merupakan frekuensi kemunculan awan pada bulan Februari (7, a-c) dan Maret 2010 (7, d-f) bergantung pada jenis awannya. Dari gambar ini dapat diketahui bahwa kebanyakan hujan yang terjadi adalah dari awan hujan SHL (gambar 7b dan 7e). Hujan dari awan SHL banyak terjadi di sisi luar sebelah Utara DAS dan sisi luar Tenggara DAS. Sedangkan di dalam DAS tampak awan-awan SHL ini berkumpul di sisi Barat danau Towuti, tersebar dari utara sampai ke selatan. Awan-awan hujan STR (gambar 6a dan 6d) banyak terlihat di tenggara DAS, dan awan hujan CNV (gambar 7c dan 7f), walaupun hanya sedikit, namun terlihat banyak terjadi di bagian tenggara DAS.

Hal ini kemungkinan berkaitan erat dengan pergerakan masa udara dan topografi wilayah tersebut. Pada bulan Februari-Maret biasanya angin berhembus dari Utara-Barat Laut (Renggono, 2011b). Di sisi Utara DAS dibatasi oleh pegunungan yang cukup tinggi, sehingga awan banyak tumbuh di wilayah tersebut. Didalam DAS tampak awan SHL juga banyak muncul di Barat danau Towuti, yang kemungkinan besar pengaruh dari efek angin danau. karena danau Towuti merupakan danau dengan permukaan air yang cukup luas. 

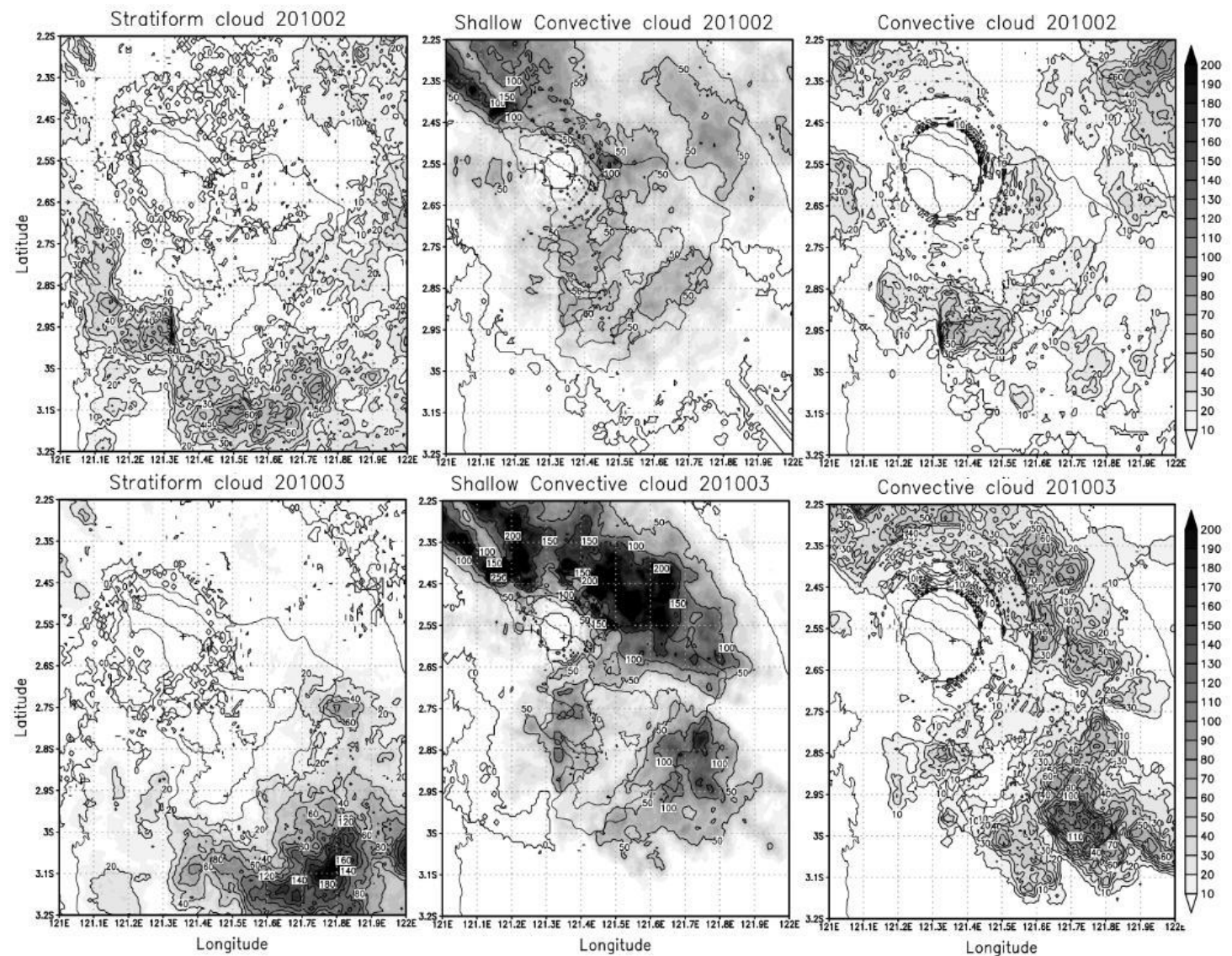

Gambar 7. Sebaran Awan berdasarkan jenis hujannya pada bulan Febuari dan Maret 2010

\section{DISKUSI}

Dari hasil analisis jenis awan, puncak kemunculan awan hujan pada pukul 13 yang terlihat pada gambar $5 \mathrm{~b}$ ternyata didominasi oleh awanawan hujan jenis SHL. Sedangkan puncak awan ke dua yang muncul setelah hujan dari awan SHL kemungkinan akibat dari hujan dari awan CNV, seperti yang terlihat pada gambar 6 (Tokalimbo bulan Januari-Februari).

Kemunculan Awan STR agak kurang terlihat dalam analisis ini, kemungkinan karena awan-awan STR banyak muncul pada malam hari. Hal ini dapat dilihat dari masih adanya hujan dengan intensitas rendah sampai malam hari. Selain itu, nilai ambang 20dBZ untuk awan STR perlu dipertimbangkan lagi.

Dalam operasi modifikasi cuaca dengan pesawat, analisis kondisi awan di dalam DAS dapat dilakukan melalui pengamatan radar secara real time. Pesawat dapat diarahkan oleh meteorologis yang bertugas di radar ke awan-awan yang potensial menghasilkan hujan. Sedangkan untuk penyemaian dari darat, sebelum membangun menara, lokasinya harus dipertimbangkan secara matang dengan tepat, agar bahan semai dapat benar-benar masuk ke dalam awan. Hasil analisis di atas menunjukkan bahwa awan-awan SHL dan
CNV banyak tumbuh di tempat yang banyak gunungnya, yaitu di batas DAS bagian Utara dan Timur.

\section{KESIMPULAN}

Dalam analisis data satelit dan juga penakar hujan diketahui bahwa musim hujan di DAS Larona adalah bulan Desember hingga Mei, hal ini sesuai dengan pola hujan monsoonal. Puncak musim hujan terjadi pada bulan April, dengan rata-rata hujan bulanan di atas $330 \mathrm{~mm}$. Pola hujan tahunan di tiga wilayah yang berada di Barat, tengah dan Timur DAS, yaitu Matano, Timampu dan Larona tidak jauh berbeda, hanya di Timampu (bagian tengah DAS) pada bulan Januari-Maret curah hujannya sedikit lebih rendah dibandingkan di kedua tempat lainnya. Dari analisis variasi harian hujan di DAS Larona menggunakan data TRMM-JAXA terlihat bahwa hujan mulai terjadi sekitar pukul 7 pagi sampai pukul 21 malam. kemunculan awan tertinggi terjadi setelah tengah hari. Bulan Januari puncak kemunculan awan lebih lambat, yaitu sekitar pukul 15 sedangkan bulan Februari dan Maret muncul sekitar pukul 13.

Awan hujan yang banyak muncul di DAS Larona adalah jenis SHL, yaitu awan-awan hujan konfektif rendah. Kemunculan awan hujan ini 
kebanyakan setelah tengah hari, sedangkan awan CNV lebih sedikit dan lebih lambat kemunculannya. Secara spasial, awan SHL dan CNV banyak muncul di sisi Utara dan Timur DAS. Di bagian tengah DAS kemunculan awan hujan ini agak sedikit, hanya terlihat di wilayah sekitar Timampu, hal ini mungkin juga dipengaruhi oleh efek angin danau. Sedangkan wilayah diatas permukaan danau hampir tidak ada awan-awan konfektif.

Dengan diketahuinya jenis awan hujan yang muncul, maka dapat diperkirakan besarnya curah hujan yang terjadi, sekaligus juga dapat digunakan sebagai peringatan jika awan hujannya berpotensi menyebabkan bencana. Dalam penelitian ini tidak dilakukan analisis tentang hubungan curah hujan permukaan dengan jenis awan awan hujan. Untuk penelitian selanjutnya kajian tentang hubungan curah hujan dan jenis awan hujan perlu dilakukan. Selain itu, metoda ini masih sangat sederhana, dengan data pengamatan yang lebih panjang dan lengkap diharapkan bisa diterapkan metode penentuan jenis awan dengan fuzzy logic seperti yang dilakukan Yang dkk (2013).

\section{REFERENSI}

Aldrian, E, Karakteristik Hujan Jam-jaman, Bulanan dan Tahunan DAS Larona, Soroako, Sulawesi Selatan, Jurnal Sains \& Teknologi Modifikasi Cuaca, 7, 43-53, 2006

Leary, C. A., and R. A. Houze Jr., The structure and evolution of convection in a tropical cloud cluster. J. Atmos. Sci., 36, 437-457, 1979

Renggono, F., H. Hashiguchi, S. Fukao, M. D. Yamanaka, S.-Y. Ogino, N. Okamoto, F. Murata, B. P. Sitorus, M. Kudsy, M. Kartasasmita, and G. Ibrahim, Precipitating clouds observed by 1.3-GHz boundary layer radars in equatorial Indonesia, Ann. Geophys., 19, 889 - 897, 2001

Renggono, Findy, Pola Sebaran Hujan di Das Larona, Jurnal Sains \& Teknologi Modifikasi Cuaca, Vol. 12, No. 1, 17-24, 2011 a

Renggono, Findy, Pengaruh ENSO terhadap Pola Angin dan Curah Hujan di DAS Larona, Sulawesi Selatan, Jurnal Sains \& Teknologi Modifikasi Cuaca, Vol. 12, No. 2, 63-68, $2011 \mathrm{~b}$

Renggono, Findy, Analisis Awan Hujan pada saat Banjir DKI dengan C-band Radar, Jurnal Sains \& Teknologi Modifikasi Cuaca, Vol. 14, No. 1, 2015

Syaifullah, Djazim. M, Validasi Data TRMM terhadap Data Curah Hujan Aktual di Tiga DAS di Indonesia, Jurnal Meteorologi dan Geofisika, Vol. 15 No. 2, 109-118, 2014

Williams, C. R., Ecklund, W. L., and Gage, K. S., Classification of precipitating clouds in the tropics using $915-\mathrm{MHz}$ wind profilers, J.
Atmos. Oceanic Technol., 12, 996-1012, 1995

Yang, Yi, Xin Chen, and Youcun Qi, Classification of convective/stratiform echoes in radar reflectivity observations using a fuzzy logic algorithm, Journal of Geophysical Research: Atmospheres, Vol. 118, 1-10, doi:10.1002/jgrd.50214, 2013

Wang, Zhien, Kenneth Sassen, Cloud Type and Macrophysical Property Retrieval Using Multiple Remote Sensors, Journal of Applied Meteorology, Vol.40, 1665-1682, 2001 